\title{
Strategi "TAK - JEMPOL (Tertib Administrasi Kependudukan dengan Jemput Bola)" bagi umat Hindu di desa Kayukebek Kecamatan Tutur Kabupaten Pasuruan
}

\section{The "TAK - JEMPOL (Orderly Administration of Occupation by Pick-up Ball)" Strategy for Hindus in Kayukebek Village, Tutur District, Pasuruan Regency}

\author{
M. Daimul Abror ${ }^{1}$ \\ ${ }^{1}$ Program Studi Administrasi Publik, FISIP, Universitas Kadiri \\ E-mail: daimabror@unik-kediri.ac.id
}

\begin{abstract}
This study aims to describe, analyze, and interpret the strategies of the village apparatus in increasing awareness of the orderly population administration in Kayukebek Village by referring to the types of strategies according to Jack Koteen including: Corporate strategy, Program strategy, Resource support strategy, and Institutional strategy. This study uses descriptive qualitative research methods. Informants from this study were the Village Head, Village Secretary as an important role holder in village government decisions, the Head of Population Administration Services and the traditional head of Hindus as key informants who knew the problems that occurred, the community as many as 1-2 people as representatives of each village. The results showed, firstly, the condition of population administration in Kayukebek Village, especially among Hindus, has now begun to be orderly where the community was previously unresponsive, now they have begun to understand and realize the importance of population administration. Second, there are several factors that cause residents to lack an orderly population administration, one of which is that people complain about the high cost, the distance to the village hall is far and the community lacks awareness from the start so that when there is a sudden need they just take care of it, such as the need for entry registration requirements. school, wedding and so on. Third, the strategy of the village apparatus in increasing awareness of the orderly population administration among Hindus, among others, by conducting socialization of population administration, utilization of human resources, increasing the ability of village officials to coordinate and cooperate with institutions related to population administration and bring services closer directly. to society.
\end{abstract}

Keywords: Strategy, Village Apparatus, Population Administration, Hindu

\begin{abstract}
Abstrak
Penelitian ini bertujuan mendeskripsikan, menganalisis, dan menginterpretasikan strategi aparatur Desa dalam meningkatkan kesadaran tertib administrasi kependudukan di Desa Kayukebek dengan mengacu pada tipe-tipe strategi menurut Jack Koteen meliputi: Corporate strategy, Program strategy, Resource support strategy, dan Institutional strategy. Penelitian ini menggunakan metode penelitian kualitatif deskriptif.
\end{abstract}


Informan dari penelitian ini adalah Kepala Desa, Sekretaris Desa sebagai pemegang peranan penting dalam keputusan pemerintahan Desa, Kaur bagian pelayanan administrasi kependudukan dan kepala adat umat Hindu sebagai informan kunci yang mengetahui permasalahan yang terjadi, masyarakat sebanyak 1-2 orang sebagai perwakilan dari masing-masing Dusun. Hasil penelitian menunjukkan, pertama kondisi administrasi kependudukan di Desa Kayukebek khususnya kalangan umat Hindu saat ini sudah mulai tertib dimana masyarakat dulunya tidak respon sekarang sudah mulai mengerti dan sadar akan pentingnya administrasi kependudukan. Kedua terdapat beberapa faktor yang menyebabkan warga kurang tertib administrasi kependudukan salah satunya yaitu masyarakat mengeluhkan akan biaya yang mahal, jarak tempuh ke balai desa jauh dan masyarakat kurang memiliki kesadaran dari awal sehingga ketika ada keperluan mendadak saja mereka baru mengurusnya, seperti kebutuhan untuk persyaratan pendaftaran masuk sekolah, pernikahan dan lain sebagainya. Ketiga, strategi aparatur desa dalam meningkatkan kesadaran tertib administrasi kependudukan di kalangan umat Hindu upaya yang dilakukan antara lain dengan mengadakan sosialisasi administrasi kependudukan, pemanfaatan sumber daya manusia, meningkatkan kemampuan aparatur desa untuk melakukan koordinasi dan kerjasama dengan instansi terkait administrasi kependudukan dan mendekatkan pelayanan secara langsung kepada masyarakat.

Kata Kunci: Strategi, Aparatur Desa, Aministrasi kependudukan, Umat Hindu

\section{Pendahuluan}

Aparatur pemerintah dalam menjalankan tugas dan fungsinya memiliki dua posisi yakni sebagai abdi negara dan abdi masyarakat. Sebagai abdi negara aparatur harus menjaga keutuhan Negara Kesatuan Republik Indonesia (NKRI) dan menjunjung tinggi rasa persatuan dan kesatuan bangsa Indonesia. Sedangkan sebagai abdi masyarakat pemerintah harus memiliki kecakapan untuk memberikan pelayanan secara optimal yang salah satu dari pelayanan itu adalah Administrasi Kependudukan. Dalam hal ini pemerintah harus memiliki strategi untuk mewujudkan hal tersebut, keberhasilan suatu organisasi ditentukan oleh kemampuan pimpinan organisasi itu menetapkan strategi yang tepat dalam menjalankan organisasinya dan memanfaatkan lingkungan, dengan memilih pengorganisasian sumber daya internal yang tepat. Ketetapan strategi yang diterapkan pimpinan suatu organisasi, didasarkan pada pemikiran stratejik yang dimilikinya dengan pengalaman pembelajarannya dalam situasi lingkungan yang terus berubah (dalam Assauri 2016:9), yang mana strategi merupakan prioritas atau arah keseluruhan yang luas yang diambil oleh organisasi. Strategi adalah pilihan-pilihan tentang bagaimana cara terbaik untuk mencapai misi organisasi Nugraha (2007:12). 
Berdasarkan Peraturan Daerah Kabupaten Pasuruan Nomor 1 Tahun 2015 tentang perubahan atas Peraturan Daerah Kabupaten Pasuruan Nomor 5 Tahun 2012 tentang penyelenggaraan administrasi kependudukan dan retribusi penggantian biaya cetak Kartu Tanda Penduduk dan Akta Pencatatan Sipil. Dijelaskan bahwa administrasi kependudukan adalah rangkaian kegiatan penataan dan penertiban dokumen dan data kependudukan melalui pendaftaran penduduk, pencatatan sipil, pengelolaan informasi administrasi kependudukan serta pendayagunaan hasilnya untuk pelayanan publik dan pembangunan sektor lain. Administrasi kependudukan sebagai suatu sistem diharapkan dapat diselenggarakan sebagai bagian dari Penyelenggara Administrasi Negara. Dari sisi kepentingan penduduk, administrasi kependudukan memberikan pemenuhan hak-hak administratif seperti pelayanan publik serta perlindungan yang berkenaan dengan dokumen kependudukan tanpa adanya perlakuan yang diskriminatif. Penyelenggaraan administrasi kependudukan Kabupaten Pasuruan pada pasal 1 pegawai yang diberi tugas dan tanggungjawab memberikan pelayanan peloporan peristiwa kependudukan dan peristiwa penting serta pengelolaan dan penyajian data kependudukan di Desa/Kelurahan atau nama lainnya.

Pada umumnya, segala bentuk pengelolahan dan penyajian informasi data kependudukan sangatlah penting keberadaanya, mengingat sebagai warga negara yang baik dan tertib hukum kita harus mengikuti tatacara yang telah ditetapkan. Manfaat yang paling dirasakan apabila kita mentaati apa yang sudah ditetapkan dalam hal tertib administrasi kependudukan yaitu kita sebagai warga negara Indonesia selain dilegalkan kebenarannya juga dilindungi hukum dimanapun kita berada. Manfaat tersebut secara langsung dirasakan salah satunya dan yang utama adalah bagi kepemilikan akta kelahiran, dalam Nazaruddin (2015:287).Di Kecamatan Tutur Kabupaten Pasuruan, Desa Kayukebek merupakan salah satu Desa yang penduduknya terdapat dua keyakinan yakni agama Islam dan agama Hindu. Desa kayukebek memiliki 5 Dusun yang mana di 3 Dusun yaitu Surorowo, Ledok, dan Ngaruh terdapat sebagian penduduk yang berkeyakinan Hindu. Mengenai administrasi kependudukan terdapat kesamaan antara agama islam dan hindu, hanya saja terdapat 1 perbedaan yaitu mengenai surat/akta nikah.

Sesuai dengan Undang-undang Nomor 1 Tahun 1974tentang Perkawinan merujuk pada pasal 2 ayat 1 dan ayat 2 menjelaskan bahwa bagi mereka yang melakukan perkawinan menurut agama islam pencatatan dilakukan di Kantor Agama Islam (KUA) 
ditingkat Kecamatan, pada umumnya dilaksanakan bersamaan dengan upacara akad nikah karena petugas pencatat nikah dari KUA hadir dalam acara akad nikah tersebut. Sedang bagi yang beragama lain seperti Hindu akta pernikahan dilaporkan dan didapatkanlangsung di Kantor Pencatatan Sipil setelah kedua mempelai melakukan pernikahan sesuai agamanya.

Selama ini dokumen kependudukan yang masyarakat ketahui dokumen yang penting hanyalah KTP dan KK, padahal masih ada dokumen lainnya yaitu akta kelahiran, perkawinan dan kematian. Kondisi saat ini yang ada di Desa Kayukebek banyaknya penduduk yang beragama Hindu tidak memiliki surat perkawinan ataupun akta nikah. Sampai kondisi mereka sudah menjadi seorang kakek dan nenek status pernikahan mereka yaitu siri (jika dalam istilah hukum islam) dan bisa dikatakan pernikahan mereka tidak berdasarkan undang-undang. Hal tersebut berdampak kepada anak-anak mereka yang tidak memiliki akta kelahiran, seorang anak bisa saja memiliki akta kelahiran tetapi status anak sebagai anak dari seorang ibu tidak tercantumkan nama ayahnya. Salah satu penyebabnya adalah masyarakat tidak mengerti akan pentingnya kepemilikan akta kelahiran, ada juga yang mengerti tetapi tidak mau mengurus.Disisi lain ketidakpunyaan akta perkawinan sangat merugikan eksistensi umat hindu baik ditinjau dari aspek moral, psikologi maupun administratif. Dalam hal ini secara moral tidak dapat menepati aturan hukum yang berlaku, secara psikologis merasa tertekan batin dan secara adminitratif umat hindu tidak akan memiliki data yang valid tentang jumlah umat pada lembaga statistik pemerintahan (Parisadapesisirselatan.wordpress.com).

Berdasarkan teori dari Jack Koteen dalam Salusu (2006:104-105) yang mengungkapkan 4 tipe strategi, aparatur Desa Kayukebek sudah menerapkan 2 tipe strategi yang pertama program strategy dilaksanakan dalam bentuk mendatangkan beberapa aparatur Dinas Kependudukan dan Pencatatan Sipil Kabupaten Pasuruan pada bulan November 2016 untuk melakukan sosialisasi mengenai pentingnya administrasi kependudukan serta memberikan kemudahan kepada masyarakat untuk mengurus secara langsung kepada pihak catatan sipil pada waktu itu. Yang kedua yaitu resource support strategy dalam hal ini aparatur Desa Kayukebek menunjuk salah satu tokoh agama umat hindu menjadi aparatur desauntuk membantu proses pengurusan administrasi kependudukan umat Hindu terutama mengenai akta perkawinan. Tetapi adanya dua 
strategi tersebut masyarakat masih saja kurang sadar terhadap pentingnya administrasi kependudukan dan bisa dikatakan strategi yang dilakukan kurang optimal.

\section{Metode Penelitian}

Metode penelitian yang digunakan dalam penelitian ini adalah metode penelitian kualitatif deskriptif. Menurut Sambas (2014:90) Penelitian kualitatif adalah penelitian yang bertujuan untuk mendapatkan pemahaman yang mendalam tentang masalahmasalah manusia dan sosial, bukan mendeskripsikan bagian permukaan dari suatu realitas sebagaimana dilakukan penelitian kuantitatif dengan positivismenya. Penelitian menginterpretasikan bagaimana subjek memperoleh makna dari lingkungan sekeliling, dan bagaimana makna tersebut mempengaruhi perilaku mereka. Penelitian dilakukan dalam latar (setting) yang alamiah (naturalistic) bukan hasil perlakuan (treatment) atau manipulasi variabel yang dilibatkan. Fokus penelitian ini adalah mengenai strategi aparatur Desa dalam meningkatkan kesadaran tertib administrasi kependudukan di kalangan umat Hindu studi di Desa Kayukebek Kecamatan Tutur Kabupaten Pasuruan. Adapun fokus penelitiannya sesuai dengan tipe-tipe strategi menurut Jack Koteen dalam salusu (2006:104-105), meliputi Corporate strategy, Program strategy, Resource support strategy, dan Institutional strategy. Penelitian ini dilakukan di Desa Kayukebek Kecamatan Tutur Kabupaten Pasuruan. Dalam penelitian ini teknik pengumpulan datanya menggunakan obsevasi, wawancara dan dokumentasi. Adapun teknik analisis datanya menggunakan teknik analisis data model interaktif yang digagas oleh Miles, Huberman dan Saldana (2014:31) meliputi kondensasi data, penyajian data dan penarikan kesimpulan/verifikasi.

\section{Kerangka Teori \\ Konsep Strategi}

Nugraha (2007:12) kata strategi berasal dari bahasa Yunani yaitu "strategos" yang terdiri dari dua suku kata yaitu "stratos" yang berarti militer dan "Ag" yang berarti memimpin. Pada konteks permulaannya, strategi banyak diasumsikan sebagai sesuatu yang dilakukan oleh para jenderal dalam membuat rencana menaklukkan atau mengalahkan musuh guna meraih kemenangan dalam perang. Oleh karena itu, sangatlah masuk akal apabila istilah ini sangat dekat dengan dunia militer dan politik.Ditinjau dari 
segi terminologi, banyak ahli yang telah mengemukakan definisi strategi dengan sudut pandang yang berbeda-beda diantaranya : (1) David (2010:8) mengemukakan bahwa strategi adalah sarana bersama dengan tujuan jangka panjang hendak di capai; (2) Taufiqurrohman (2016:19) strategi didefinisikan sebagai sekumpulan komitmen dan tindakan yang terkoordinasi yang dirancang untuk mengeksploitasi kompetensi dan mencapai keunggulan organisasi.

Strategi sebenarnya merupakan pemilihan yang dilakukan secara matang atas serangkaian tindakan atau cara yang dilakukan, sebagai upaya untuk mencapai satu atau beberapa tujuan yang telah ditetapkan. Dengan demikian istilah "strategi" dirumuskan sebagai suatu tujuan yang ingin dicapai, upaya untuk mengkomunikasikan apa saja yang akan dikerjakan, oleh siapa yang mengerjakannya, bagaimana cara mengerjakannya, serta kepada siapa saja hal-hal tersebut pula dikomunikasikan, dan juga perlu dipahami mengapa hasil kinerja tersebut perlu dinilai. Secara jelas "strategi" diarahkan atau dialamatkan, bagaimana organisasi itu berupaya memanfaatkan atau mengusahakan agar dapat mempengaruhi lingkungannya, serta memilih upaya pengorganisasian internal, dimana yang terakhir ini bukan merupakan bagian dari strategi (Jurnal Assauri,2016:23).Proses atau pembuatan strategi mengacu pada bagaimana tujuan dan tindakan yang dipilih atau dirumuskan, Hart dalam Boyne (2004:232).

Pentingnya strategi

Ibrahim (2013:25-26) mengatakan bahwa strategi penting karena: (1) Hasil pertimbangan dan pemikiran yang analitis dan konseptual mengenai hal-hal penting dan bersifat prioritas yang menjadi acuan untuk menetapkan langkah-langkah berikutnya. (2) Merupakan proses untuk menentukan arah yang harus dijalani agar visi dan misi tercapai (memperkuat visi dan misi). (3) Memberikan dasar yang masuk akal untuk keputusankeputusan yang akan terfokus pada arah yang benar. (4) Membantu menghindari dari jalan yang berbelit-belit karena merupakan rute yang jelas menuju tempat persinggahan akhir. (5) Menentukan arah untuk “ kesepakatan bersama”. (6) Memberikan arah yang jelas karena memuat formulasi sasaran jangka panjang, pemilihan tindakan-tindakan, alokasi serta pemanfaatan sumber daya sebaik-baiknya. (7) Menghemat waktu dan biaya. 


\section{Tipe-Tipe Strategi}

Pada dasarnya setiap organisasi memiliki strategi untuk mencapai tujuan yang diinginkan, akan tetapi tipe-tipe startegi yang digunakan dalam organisasi berbeda-beda tergantung dari apa permasalahannya dan bagaimana cara yang harus dilakukan untuk menyelesaikannya. Jack Koteen dalam salusu (2006:104-105) mengungkapkan bahwa dalam strategi terdapat beberapa tipe-tipe strategi, diantaranya:

1. Corporate strategy (strategi organisasi): Strategi ini berkaitan dengan perumusan misi, tujuan, nilai-nilai dan inisiatif-inisiatif strategi yang baru. Pembatasanpembatasan diperlukan, yaitu mengenai apa yang dilakukan dan untuk apa.

2. Program strategy (strategi progam): Strategi ini lebih memberikan perhatian pada implikasi-implikasi strategi dari suatu program tertentu. Kira-kira apa dampaknya apabila suatu program tertentu dilancarkan atau diperkenalkan (apa dampaknya bagi sasaran organisasi).

3. Resource support strategy (strategi pendukung sumber daya): Strategi ini memusatkan perhatian pada memaksimalkan pemanfaatan sumber-sumber daya esensial yang tersedia guna meningkatkan kualitas kinerja organisasi. Sumber daya itu dapat berupa tenaga, keuangan, teknologi dan sebagainya.

4. Institutional strategy (strategi kelembagaan): fokus dari strategi institusional ialah mengembangkan kemampuan organisasional untuk melaksanakan inisiatifinisiatif startegi.

\section{Hasil dan Pembahasan}

Dalam penyajian data, peneliti menyajikan informasi tentang hasil penelitian yang diperoleh dari berbagai sumber penelitian, baik itu wawancara maupun dokumentasi. Berikut adalah data informan yang memberikan informasi dalam penelitian ini, diantaranya: 
Tabel 1

Informan Penelitian

\begin{tabular}{|l|l|l|}
\hline No. & \multicolumn{1}{|c|}{ Nama } & \multicolumn{1}{|c|}{ Jabatan } \\
\hline 1. & Istantono & Kepala Desa \\
\hline 2. & Wagiso & Kaur tata usaha \& Kearsipan \\
\hline 3. & Ninik Purwatiningsih & Kasi Pelayanan \\
\hline 4. & Dewi Sulifin S.Pdi & Bendahara \\
\hline 5. & Wahyu & Kasun Dusun Surorowo \\
\hline 6. & Jiyana & Warga Dusun Surorowo \\
\hline 7. & Yuar & Warga Dusun Surorowo \\
\hline 8. & Sudiana & Warga Dusun Ledok \\
\hline 9. & Suti & Warga Dusun Ledok \\
\hline 10. & Marjuki & Kasun Ngaruh \\
\hline
\end{tabular}

Sumber: Hasil penelitian peneliti, 2021

\section{a) Kondisi tertib administrasi kependudukan di Desa Kayukebek}

Kondisi administrasi kependudukan di Desa Kayukebek secara umum dikatakan tertib dalam arti untuk kepengurusan ktp dan kartu keluarga dari tahun ke tahun mengalami peningkatan sedikit demi sedikit, akan tetapi untuk administrasi kependudukan yang berupa akta kelahiran kurang tertib.Dari hasil wawancara, observasi dan data kependudukan kami paparkan dalam bentuk tabel sebagai berikut:

Tabel 2

Data administrasi kependudukan

\begin{tabular}{|c|c|c|c|c|}
\hline \multirow[t]{2}{*}{ No. } & \multirow{2}{*}{$\begin{array}{c}\text { Bentuk administrasi } \\
\text { kependudukan }\end{array}$} & \multirow{2}{*}{$\begin{array}{c}\text { Jumlah yang } \\
\text { mengurus }\end{array}$} & \multicolumn{2}{|c|}{ Tertib } \\
\hline & & & Iya & Tidak \\
\hline 1. & Kartu Keluarga (KK) & 89 & $\sqrt{ }$ & \\
\hline 2. & Kartu Tanda Penduduk (KTP) & 69 & $\sqrt{ }$ & \\
\hline 3. & Akta Kelahiran & 57 & & $\sqrt{ }$ \\
\hline 4. & Akta perkawinan & 79 & & $\sqrt{ }$ \\
\hline
\end{tabular}

Sumber: rekapitulasi data administrasi kependudukan Desa Kayukebek Tahun 2015-2020 
Dari tabel diatas sudah jelas bahwa kondisi administrasi kependudukan di Desa Kayukebek khususnya warga umat Hindu dikatakan tertib dalam kepengurusan KK dan KTP saja, untuk data KK, KTP dan akta kelahiran kami dapatkan dari tahun 2015 sampai bulan Juni tahun 2020, mengenai akta kelahiran dikatakan tidak tertib karena jumlah anak usia 0-6 Tahun berjumlah 81 anak sedangkan yang mengurus hanya 57 anak. Belum lagi hasil observasi kami di lapangan yang menemukan masih banyaknya usia SD yang seharusnya sudah memiliki akta kelahiran tetapi belum memilikinya. Untuk data akta perkawinan kami dapatkan selama 5 tahun terakhir dari tahun 2015-2020 jumlah keseluruhan umat hindu yang melaporkan pernikahannya ke Desa dan untuk didaftarkan ke Dinas Kependudukan dan Pencatatan Sipil Kabupaten Pasuruan hanya 79 saja. Selebihnya itu hanya sebatas mendapatkan akta perkawinan dari kepala adat saja sehingga dapat dikatakan tidak tertib.

\section{b) Faktor yang menyebabkan kurang sadarnya tertib administrasi kependudukan}

Berdasarkan hasil wawancara, observasi dan dokumentasi yang penulis lakukan di Desa Kayukebek, terdapat beberapa faktor yang menyebabkan kurang sadarnya tertib administrasi kependudukan, diantaranya:

1. Masyarakat lebih memilih memanfaatkan waktunya untuk bekerja di kebun dari pada bolak-balik ngurusi akta kelahiran.

2. Masyarakat tidak mengetahui akan pentingnya administrasi kependudukan khususnya akta perkawinan dan akta kelahiran.

3. Ada yang mengerti akan pentingnya memiliki akta kelahiran untuk anaknya tetapi mereka tidak mau mengurus "malas".

4. Biaya untuk membuat akta kelahiran terkesan mahal.

5. Warga Dusun Surorowo mengeluhkan mengenai jarak yang jauh, bisa dikatakan Dusun yang terpencil.

6. Masyarakat mau mengurus ketika ada kepentingan mendadak saja, seperti untuk pendaftaran masuk ke sekolah, mau menikah, kepentingan pekerjaan dan lainlain. 
Abror: " Strategi "TAK - JEMPOL ..."

\section{c) Strategi aparatur Desa dalam meningkatkan kesadaran tertib administrasi kependudukan di kalangan umat Hindu}

Administrasi kependudukan sangatlah penting karena merupakan bentuk identitas diri dari seseorang serta untuk mendapatkan hak perlindungan dari negara, namun saat ini yang terjadi di Desa Kayukebek warga umat Hindu belum sadar akan pentingnya administrasi kependudukan sehingga dikatakan kurang tertib. Dalam hal ini maka perlu adanya strategi yang harus dilakukan oleh aparatur desa untuk meningkatnya administrasi kependudukan terutama dikalangan umat Hindu yang mana kami menemukan berbagai permasalahan. Ada berbagaimacamstrategi yang dilakukanaparaturDesa Kayukebekdiantaranya:

\section{1) Sosialisasi administrasi kependudukan}

Dalam rangka meningkatkan tertib administrasi kependudukan di Desa Kayukebek khususnya kalangan umat Hindu langkah pertama yang dilakukan oleh kepala desa dan kasi pelayananadalah sosialisasi mengenai administrasi kependudukan, adapun tujuan diadakannya sosialisasi yakni menyampaikan kepada masyarakat agar lebih memahami tentang pentingnya administrasi kependudukan dan pencatatan sipil bagi dirinya maupun keluarga dan masyarakat, untuk meningkatkan tertib administrasi dalam pelaksanaan dan pelayanan dokumen kependudukan. Memberitahukan kepada masyarakat mengenai alur serta syarat-syarat untuk kepengurusan administrasi kependudukan. Dan juga sosialisasi tersebut berguna untuk masukan bagi petugas dinas kependudukan dan pencatatan sipil dalam memperbaiki kinerja aparaturnya selain itu menjadi acuan dalam pelaksanaan administrasi kependudukan kedepan agar lebih baik lagi dengan mengutamakan kepuasan masyarakat serta terciptanya pelayanan yang tidak ribet dan berbelit-belit.

\section{2) Pemanfaatan sumber daya manusia (SDM)}

Pemanfaatan sumber daya manusia (SDM) merupakan strategi yang dilakukan oleh kepala Desa dengan memanfaatkan sumber daya manusia yang ada dengan sebaik mungkin, karena SDM disini mempunyai pengaruh terhadap kualitas dan kepuasan masyarakat terhadap pelayanan yang diberikan. Kemampuan dan kecakapan dari aparatur desa dibutuhkan agar pelayanan yang diberikan efektif dan 
efisien, sesuai dengan Jack Koteen dalam salusu (2006:104-105) bahwa memaksimalkan pemanfaatan sumber-sumber daya esensial yang tersedia guna meningkatkan kualitas kinerja organisasi. Sumberdayaitudapatberupatenaga, keuangan, teknologidansebagainya.

Adapun bentuk dari pemanfaatan SDM yang dilakukan oleh aparatur Desa diantanya dengan perombakan struktur pemerintahan Desa Kayukebek dengan kasi pelayanan beragama Hindu dalam hal ini saya menilai upaya yang dilakukan dapat optimal karena selama ini banyaknya warga umat Hindu yang kurang tertib mengenai administrasi kependudukan, tetapi disisi lain dari hasil pengamatan penulis menilai bahwa Ibu Ninik ini masih belum terlalu faham dan mengetahui secara detail mengenai administrasi kependudukan, beliau ini masih mengandalkan bapak Wagiso dan Ibu Sulipin yang sudah berpengalaman. Hal tersebut dibuktikan ketika kami wawancara mengenai administrasi kependudukan beliau selalu mengarahkan agar kami bertanya kepada bapak Wagiso dan Ibu Sulipinn yang lebih tahu "tuturnya".

Pemanfaatan sumber daya manusia yang lain yaitu adanya pelatihan administrasi yang diberikan mahasiswa KKN Unitomo Surabaya yang diharapkan menambah pengetahuan serta kemampuan aparatur Desa, selain itu Ibu Ninik menerapkan disiplin waktu dengan hadir di kantor Balai Desa pada pukul 09.30 WIB yang datang terlebih dahulu dari aparatur Desa lainnya yang bertujuan agar dapat memberikan pelayanan kepada masyarakat secara efektif dan efisien. Hal tersebut dibuktikan ketika kami beberapa kali ke balai desa untuk kepentingan observasi, wawancara dan lain-lain perangkat Desa yang pertama kami jumpai di Balai Desa Yaitu Ibu Ninik. Sedangkan kepala Desa beserta aparatur yang lain datangnya sekitar pukul 09.30 WIB. Bisa dikatakan beliau ini disiplin waktu.

\section{3) Meningkatkan kemampuan aparatur desa untuk melakukan koordinasi dan} kerjasama dengan instansi terkait administrasi kependudukan

Selain sosialisasi dan pemanfaatan sumber daya manusia, strategi lain yang dilakukan oleh Kepala Desa Kayukebek yakni dengan meningkatkan kemampuan aparatur desa untuk melakukan koordinasi dan kerjasama dengan instansi terkait administrasi kependudukan. Dalam hal ini aparatur Desa bagi tugas, ada yang standby di kantor Balai Desa untuk memberikan pelayanan kepada masyarakat ada juga yang 


\section{Abror: " Strategi "TAK - JEMPOL ..."}

bertugas riwa-riwi ke Kecamatan, UPT, dan Dinas Kependudukan. Selain bertujuan untuk mengurus kepentingan administrasi kependudukan juga dimanfaatkan untuk menjalin kedekatan atau melakukan koordinasi dengan pihak terkait administrasi kependudukan.

Setiap kali kami ke kantor Desa untuk menemui bapak Wagiso dan Ibu Sulipin beliau jarang ada di Kantor Desa, aparatur desa lain mengatakan kalau Ibu Sulipin atau Bapak Wagiso ke Kecamatan atau ke UPT dan juga ke Dinas Kependudukan. Strategi yang dilakukan ini menurut kami cukup baik karena denga terciptanya koordinasi dan kerjasama dengan instansi administrasi kependudukan akan mempermudah aparatur desa dalam membantu masyarakat untuk mengurus segala hal, jika ada permasalahan dapat langsung dikonsultasikan dan juga informasi yang didapatkan ter up to date.

\section{4) Mendekatkan pelayanan secara langsung kepada masyarakat}

Strategi selanjutnya yang dilakukan oleh aparatur Desa yaitu mendekatkan pelayanan secara langsung kepada masyarakat. Adapun bentuk pelayanan tersebut yaitu dengan mengadakan program masal perdusun. Secara langsung aparatur Desa terjun ke lapangan untuk memberikan pelayanan administrasi kependudukan jadi masyarakat tidak perlu ribet datang ke balai desa tetapi disini aparatur desa yang datang ke lingkungan warga. Diantara strategi yang lain menurut penulis strategi ini yang paling optimal, karena dengan adanya program masal perdusun ini berarti memberikan kemudahan kepada masyarakat serta terwujudnya tertib administrasi kependudukan yang menguntungkan warga serta aparat desa, dengan begitu dapat terpenuhinya data statistik administrasi kependudukan ditingkat desa.

\section{Kesimpulan}

Berdasarkan analisa data diatas yang berdasarkan hasil wawancara, observasi serta dokumentasi, maka dalam penelitian yang dilakukan diperoleh sebuah kesimpulan sebagai berikut: (1) Kondisi administrasi kependudukan saat ini di kalangan umat Hindu dikatakan sudah mulai tertib, masyarakat yang dulunya tidak respon sekarang sudah mulai sadar akan pentingnya administrasi kependudukan, tetapi ada sebagian warga yang enggan mengurus, bila ada kebutuhan mendadak saja mereka baru mengurusnya, hal ini 
dibuktikan dengan hasil observasi dan wawancara kami di Dusun Ngaruh dan Dusun Surorowo, terutama di Dusun Surorowo yang letaknya sangat jauh dari dusun-dusun yang lain dan keseluruhan anak-anak disana langsung masuk SD, sehingga kesadaran akan kepemilikan akta kelahiran sejak lahir masih sangat minim. (2) Berdasarkan hasil penelitian, penulis menyimpulkan ada beberapa faktor yang menyebabkan warga umat Hindu kurang tertib administrasi kependudukan, diantaranya warga berfikir bahwa mengurus akta kelahiran itu mahal, warga lebih memilih menggunakan waktunya untuk bekerja dari pada wira wiri mengurus administrasi kependudukan, dan warga kurang sadar akan pentingnya kepemilikan akta perkawinan dan akta kelahiran sehingga warga mengurusnya jika ada kepentingan mendadak saja. (3) Terdapat empat strategi yang diterapkan oleh aparatur Desa Kayukebek sebagai upaya untuk meningkatkan kesadaran umat Hindu terhadap pentingnya Administrasi Kependudukan, diantaranya mengadakan sosialisasi administrasi kependudukan, pemanfaatan Sumber Daya Manusia (SDM), Meningkatkan kemampuan aparatur desa untuk melakukan koordinasi dan kerjasama dengan instansi terkait administrasi kependudukan dan mendekatkan pelayanan secara langsung kepada masyarakat. Diantara keempat strategi tersebut penulis berpendapat bahwa strategi mendekatkan pelayanan secara langsung kepada masyarakat merupakan strategi yang paling optimal, dengan bentuk progam masal perdusun yang diadakan dapat memberikan keuntungan bagi aparatur desa dan juga masyarakat, untuk aparatur desa keuntungan yang didapat warga tertib administrasi kependuduk sehingga terpenuhinya statistik kependudukan di Desa maupun di tingkat Kabupaten, bagi masyarakat dapat melengkapi administrasi kependudukan yang belum dimiliki dan tidak perlu ribet ataupun bolak-balik ke balai desa.

Berdasarkan hasil kesimpulan diatas maka peneliti ingin memberikan sebuah rekomendasi untuk kemajuan kepemerintahan desa serta terwujudnya tertib administrasi kependudukan dikalangan umat Hindu, adapun saran sebagai berikut: (1) Mengadakan sosialisasi khusus bagi umat Hindu mengenai pentingnya akta perkawinan yang diterbitkan melalui dinas kependudukan dan pencatatan sipil kabupaten paasuruan. (2) Terjalinnya kerjasama yang baik antara aparatur desa khususnya bagian pelayanan Administrasi Kependudukan dengan kepala adat/bapak mudin umat Hindu. (3) Mengenai program masal perdusun menurut kami sudah baik tetapi sebaiknya menjadi program lajutan tidak hanya satu kali saja. (4) Tersedianya sarana informasi dan komunikasi bagi 
warga umat Hindu mengenai administrasi kependudukan. (5) Adanya kotak pengaduan dan keluhan dari masyarakat tentang administrasi kependudukan.

\section{Daftar Pustaka}

Assauri, Sofjan. (2016). Strategi management Sustainable competitive advantages. Ed.2. Jakarta: PT Rajagrafindo persada. diakses pada 18 Maret 2017 pada pukul 15.30 WIB

Miles, M., A.M. Huberman, and J. Saldana. (2014). Qualitative data analysis A methods sourcebook. Ed.3. America: Sage publications.

Moeleong, Lexy J. (2009). Metodologi penelitian kualitatif. Bandung: PT Remaja roskadaya offset.

Nazaruddin, Muhammad. (2015). Studi tentang efektivitas pembuatan akte kelahiran di kantor dinas kependudukan dan catatan sipil Kabupaten Berau. eJournal administrasi negara, Volume 3, nomor 1, 2015. Mahasiswa program S1 administrasi negara fakultas ilmu sosial dan ilmu politik universitas mulawarman. $285-296$

Nugraha, Qudrat. (2007). Manajemen strategis pemerintahan. Modul 1. Jakarta: Universitas terbuka.

Peraturan Daerah Kabupaten Pasuruan Nomor 1 Tahun 2015 tentang Administrasi Kependudukan dan Retribusi penggantian Biaya Cetak Kartu Tanda Penduduk dan Akta Catatan Sipil.

Salusu. (2006). Pengambilan keputusan strategik. Jakarta: PT Gramedia widia sarana indonesia.

Sambas, Saepul. (2014). Penelitian kualitatif perspektif filsafat dan budaya. Papua: PT Aseni.

Sholeh, Moh. (2015). Upaya peningkatan kemampuan aparatur desa dalam pelaksanaan tugas administrasi di Desa Morowudi Kecamatan Cerme Kabupaten Gresik. Skripsi. Program ilmu administrasi negara fakultas ilmu sosial dan ilmu politik universitas wijaya putra Surabaya.

Undang-undang Nomor 1 Tahun 1974 tentang Perkawinan 